\title{
Descritivo de UMA JORNADA
}

Carlos Gontijo Rosa

DOI 10.11606/issn.1981-7169.crioula.2017.132770

screver um trabalho acadêmico é navegar, à deriva. Solitário e mitificado como Pi, Odisseu abraçado às L. tábuas desconjuntadas por Poseidon vagando no espaço entre os braços de Calíope e Penélope. Há orientadores-faróis que te direcionam e há bolsas-correntes de ar que te levam a um caminho ou outro. $E$ há o vazio da escrita, o horizonte da página em branco, como a linha azul-azul entre céu e mar. Falta-lhe a perspectiva, faltam-nos as palavras. Mas há a viagem - e o que há nela.

Mas a metáfora por aqui se encerra, uma vez que a aridez da forma acadêmica - crítica, erudita, elaborada, enigmática - se impôs sobre minha escrita, e ora flui mais naturalmente pelos meus dedos até o computador. Mesmo trabalhando há anos em diálogo direto com a Mitologia Grega, minha escrita não alcança as metáforas bem-feitas. Às vezes, há realmente esta vontade de falar mais como os autores que estudo e menos sobre eles, mas sigo o conselho uma vez dado a um colega: "senta no canto e espera passar!"

Por fim, não trago mais do que minha história de como escrevi a Tese Antônio José da Silva: uma dramaturgia de convenções, que foi defendida no dia 05 de abril de 2017. Ou talvez de como cheguei a ela. Eventualmente, este será 
o fim do caminho, que começou numa abandonada Licenciatura em Artes Cênicas em Ouro Preto, passando por um longo Bacharelado em Artes Cênicas na UNICAMP, emendado a um Mestrado em Teoria Literária. Daí a descoberta de Antônio José da Silva e sua dramaturgia. Eventualmente este não será o fim do caminho...

Foram cinco anos e oito meses desde a decisão de prestar a prova do Doutorado em um Programa no qual apenas conhecia o autor objeto do meu Mestrado. Mas a prática em teoria e análise de textos desenvolvida na UNICAMP surtiu efeito e fui galardoado com a possibilidade de cursar o Doutoramento em Literatura Portuguesa. Era um grande desafio, pois, além de estudar meu objeto de pesquisa, precisava ser capaz de lidar com o universo de referências da Literatura Portuguesa. Um conselho não me saiu da cabeça durante todos estes anos, dado pelo Prof. Francisco Maciel Silveira: "você será doutor em Literatura Portuguesa, não em Antônio José da Silva. Seja doutor em toda a Literatura Portuguesa". Tentei segui-lo ferrenhamente. Ainda tento.

A metáfora do início do texto, embora não tão elegante quanto a de um Antônio - Vieira, Ferreira ou José da Silva -, serve a um propósito, pois minha Tese foi toda escrita em viagens - e algumas aventuras. Minha matrícula foi feita quando eu já estava há alguns dias no Timor-Leste, onde fui ministrar aulas de Língua Portuguesa na Universidade Nacional. Um amigo me mandava os "prints" das telas que deveriam ser preenchidas por e-mail, eu respondia e ele completava o formulário para mim. A internet do hotel não era suficiente para carregar a página da USP. 
Mesmo estando em vias de entrar no Doutorado na USP, decidi realizar esta viagem e desenvolver minha pesquisa concomitantemente. Uma amiga, como uma Nausícaa que incita Odisseu a contar sua jornada, me faz relembrar e reviver esse meu caminho "torto", que se desvia até o Sudeste Asiático, faz escala na Europa e volta ao Brasil. Um caminho reto, direto e objetivo em nossa formação é tão difícil quanto qualquer outro. Entretanto, quão mais ricas não são as possibilidades de elaborar diálogos entre áreas, quando o caminho é labiríntico. De uma forma ou de outra, Odisseu retorna a Ítaca, mas qual dos caminhos lhe oferecem mais histórias, mais conhecimento do mundo e de si, mais conhecimento do outro?

No Timor, pelo contato com os alunos, comecei a me indagar mais acerca das questões de leitura propriamente do que, mais especificamente, acerca de uma leitura aprofundada, demasiado hermética, dos textos. ${ }^{1}$ Como um leitor entende um texto? Como explicar para uma população faminta que aperitivo é algo que se come para abrir o apetite? Esse pontapé inicial chegaria à pergunta basilar do último ano de escrita da Tese: como explicar a um leitor contemporâneo, impregnado do pensamento romântico-positivista, um texto escrito em outros moldes, próximos, mas diferentes?

Academicamente, enquanto pesquisador, o Timor não possibilitou muitos espaços e material bibliográfico para investigação. De todo modo, eu voltei de lá outro: outro professor, outra pessoa! Entretanto, acima de tudo, eu havia ido para lá também porque precisava do trabalho e do salário. Uma vez

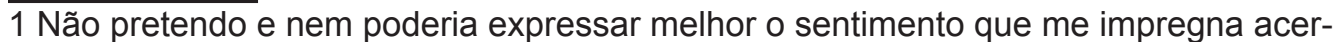
ca do Timor e dos alunos do que foi expresso pela Profa. Dra. Patricia Trindade Nakagome, no Diário Acadêmico da Revista Crioula n. 14 (2014). 
que deixaram de me pagar, busquei outras alternativas. Foi aí que um Zéfiro redirecionou meu trabalho e, com apenas seis meses enquanto aluno doutorando, fui para Portugal, ser investigador com uma Bolsa de Investigação para Estrangeiros da Fundação Calouste Gulbenkian.

O tempo no Centro de Estudos de Teatro, na Universidade de Lisboa, seguramente, foi o período mais produtivo do meu trabalho. Eu estava em Portugal! Eu tinha a Biblioteca Nacional! Eu assisti às peças do autor que eu estudava e que não eram montadas profissionalmente no Brasil há gerações! E meu projeto não fazia o menor sentido para os portugueses.

Enquanto ideia inicial - que persiste, sempre, como vontade conciliadora entre Teatro e Literatura -, minha vontade de estabelecer o diálogo entre estas duas áreas não mobilizaria nenhuma grande força em Portugal, pois não constitui nenhuma novidade, haja vista que o CET faz parte da Faculdade de Letras, mas, entre outras inúmeras atividades, mantém uma base de dados de peças teatrais apresentadas em Portugal. Ou seja, lá, no Velho Continente, estas áreas de conhecimento nunca ficaram apartadas, como são no Brasil, enquanto pesquisa. Vendo isto, observei atentamente como eles estudavam, perguntei, acompanhei pesquisas e aulas, a fim de entender sua forma de entendimento, com o objetivo de não ficar mais "em cima do muro" entre a Literatura e o Teatro. Não há muro!

Sempre havia me deparado com muros. Quando discordava ou ajustava conceitos dos colegas em discussões na Graduação. Quando lecionei, por um ano, em Porto Alegre. Quando "mudei de área" e fui para a Teoria Literária no Mestrado. Sempre que montava alguma peça, eu era o teórico 
"cabeção". Sempre que participava de congressos ou aulas de Literatura, eu era "o menino do teatro" e nunca passei sem a pergunta: "como isso é montado?"

Sabendo, agora, que não havia muro, voltei ao Brasil. Meu texto, 200 páginas ainda "teóricas", buscava explorar a construção de personagens mitológicas nas peças de Antônio José. Elas encerravam o muito que havia achado nas bibliotecas e nos centros de documentação portugueses, textos clássicos visitados sob a óptica dos textos de Antônio José. Um trabaIho quase taxonômico, que foi muito gentilmente avaliado pela minha banca de Qualificação. Esta, mais um marco, mais uma Melinde camoniana posta no meu caminho.

Antes de qualificar-me ( $\mathrm{sic}$ ), porém, mais uma "experiência antropológica" me fez novamente voltar o olhar para a leitura e para como as pessoas leem textos dramáticos antigos - ou textos antigos, ou textos dramáticos - hoje em dia. Fui, a convite de uma amiga, ministrar aulas de Literatura Dramática na Universidade Federal do Tocantins durante as minhas "férias". Como o calendário das federais estava descompassado por causa das (inúmeras) greves recentes, estive lá não para disciplinas de férias, mas para regulares.

Aí, percebi que a realidade universitária não é díspar apenas entre países, mas também dentro do nosso próprio território. Não trato de uma questão qualitativa do Ensino Superior Brasileiro, mas de deficiências de formação de base - que, como bem sabemos (na teoria, ao menos), podem ser de ordem meramente educacional, mas também de condições de vida, alimentação, dentre outros. De concreto, apenas trouxe comigo a necessidade de ensinar as pessoas a 
ler e a se aproximar de um texto sem um estranhamento a cada página. E mais: que eu não preciso falar a quem já sabe, ou seja, como educador, eu deveria reaprender a falar acerca do texto dramático no sentido de conduzir quem quer que seja por sua leitura.

Mas o meu projeto não era exatamente sobre isso, portanto, como conciliar interesses novos e antigos? Na Qualificação e nos meses que a sucederam, conversei quase monotematicamente sobre isso com quem quer que passasse pela minha frente.

Voltando ao projeto de Doutorado, entre os sempre muitos apontamentos feitos na Qualificação, o Prof. João Roberto, de quem eu seria estagiário em semestres posteriores e que acompanharia de perto meu crescimento a partir dali, "avisou-me" que o meu projeto não era um projeto de Doutoramento, mas um projeto de vida. Acedi e tornei-me menos megalomaníaco. Isso me permitiu, quando consegui organizar tudo aquilo que fervilhava em minha mente, ter espaço para esta nova viagem, que se insinuava ainda muito sutilmente.

Se minha orientadora já havia me alertado diversas vezes, em variadas ocasiões, da impossibilidade de realização do intento original da Tese? Sim. Mas a desobediência argumentada é uma prática que desenvolvi durante minha vida acadêmica e ela, com sua experiência, sabia que eu reconheceria a derrota em algum momento.

O período depois da Qualificação foi o mais difícil academicamente. Ao se estudar um teatro europeu "menor", ou seja, que se localiza distante em termos geográficos, temporais e de relevância consagrada, como empreender o "sal- 
to" qualitativo entre a mera pesquisa informativa e ler algo "novo" naqueles textos? Neste sentido, a internet e a reserva técnica da bolsa FAPESP foram importantes, pois me permitiram acesso a diversos materiais. Entretanto, e aprendi isso de um baque, a pesquisa in loco ainda é aquela que nos revela mais coisas.

Portanto, depois de alguns meses não encontrando um direcionamento à pesquisa que respondesse aos meus anseios de pesquisador e ao que eu acreditava ser o caminho a seguir, desta vez Bóreas me direciona a Madri, mais especificamente à Universidad Complutense de Madrid, onde, pelas mãos do Prof. Javier Huerta Calvo, meu Dédalo literário, foi-me apresentado um novo mundo, baseado em um conceito antigo para mim, com o qual tive contato no primeiro ano de Graduação na UNICAMP com o falecido Prof. Rubinho: a carnavalização bakhtiniana.

Foi como se apenas a frente do palco, até agora, estivesse iluminada, numa luz especialmente recortada a fim de pensarmos que aquilo é o mundo a ser apresentado. Entretanto, quando se abre a luz geral, ela se esparrama por lugares até agora não imaginados. Não vejo apenas o fundo do palco, mas as coxias, a gambiarra, as roldanas, ou seja, todo o mecanismo dissecado por Bakhtin, no livro A cultura popular na Idade Média e no Renascimento: o contexto de François Rabelais, aplicado ao Teatro! E, mais especificamente, à literatura dramática do Século de Ouro espanhol, primo-irmão da dramaturgia de Antônio José da Silva.

Aquilo, portanto, que eram para ser quatro meses de uma viagem prazerosa, com a finalidade apenas de escrever mais 
algumas páginas acerca de cada peça - afinal, 200 páginas já é muito! -, tornou-se uma verdadeira cruzada para conseguir angariar a maior quantidade possível de material para trazer ao Brasil. O que eu conheci da Espanha? As paredes da Biblioteca Nacional e das bibliotecas da UCM.

Até aquele momento, ainda não havia um Doutorado, ou o que eu entendia por isso. Havia análises, mais ou menos interessantes, de aspectos da dramaturgia de Antônio José, mas não algo que eu pudesse chamar de "novo". Trazer aquela teoria para o Brasil, apresentá-la ao meio acadêmico brasileiro, em português, seria já uma grande conquista, digna dos financiamentos até agora angariados. Entretanto, houve um problema: se nas mais antigas das cinco peças que eu estudava, a teoria se encaixava quase como uma luva, nas mais recentes, havia um descompasso entre teoria e texto. A teoria preconizava que todas as falas presentes na peça deveriam ser regidas por ao menos uma das oito funções dramáticas lá discriminadas.

Então, quinze ou vinte dias antes de voltar ao Brasil, e pensando que talvez tudo aquilo estudado com tanta pressa e afinco pudesse ser um desperdício de tempo, dinheiro e esforço, numa segunda-feira à tarde, eis que Athena (ou Melpômene, ou Talía, ou ainda uma Tágide dadivosa) desvela meu olhar e meu entendimento...Todas aquelas falas soltas, sem função ou porquê claro dentro da estrutura teórica, magicamente se juntaram num todo com sentido! Mas um sentido diverso das demais categorias, alheio a elas, mas unos em si.

Assim, com nome em espanhol e tudo, numa tarde qualquer de uma segunda-feira preguiçosa, numa biblioteca silen- 
ciosa em meio à siesta, eu só queria saltar, gritar e virar uma estrela, pois o meu Doutorado (aquilo que eu sabia que era um Doutorado) veio a mim!

Imediatamente, marquei uma reunião com meu supervisor espanhol, que prontamente me recebeu uma semana depois e, embora ele não tenha gostado nada do nome dado, o complemento à teoria, esta nova função agregada às oito preexistentes, Ihe fazia sentido! $\mathrm{E}$ como ele, falante de espanhol, não teve sugestão melhor, temos agora uma função ajena agregada ao rol de funções dramáticas presentes nos textos escritos neste período na Península Ibérica. Eu acho até que pode ser aplicada a outras dramaturgias, mas ainda não testei.

Passei a última semana desesperado atrás de bibliografia que comprovasse e, mais que isso, não desqualificasse o meu pensamento. E a Biblioteca Nacional ia fechar na Semana Santa! Claro, estava na Espanha, onde até xingamento é religioso: hostia. Então, no sábado anterior à festa divinal, eram 14h10, o bibliotecário arrancando La intriga secundaria en el teatro de Lope de Vega da minha mão e eu, desesperado porque não havia encontrado aquele livro em nenhum sebo eletrônico ou físico, terminando de copiar a última citação que não pude colocar na Tese porque ela estava muito longa. De revanche, para não ser em vão, a cito a vocês:

Los convencionalismos escénicos eran aceptados como parte del efecto ilusionista, y las intrigas secundarias y otros episodios más o menos extemporáneos eran parte de esta seductora ficción vital, inconexos pero a la vez reducibles a 
cierta unidad por virtud de la asociación temática. (MARÍN, 1958, p. 177).

Se este "libro" tivesse sido publicado em 1960, eu poderia tirar cópias disso². Um tempo depois, ainda em 2015, encontrei um exemplar em um site. Paguei o que foi pedido e o livro veio sem as páginas que eram relevantes para a minha Tese, em que o autor descreve teoricamente os tipos de intriga secundária. Depois de infernizar a vida do livreiro que me vendeu o livro, uma amiga que, na altura, estava na Espanha, foi impelida a oferecer-se a ir à BNE e tirar fotos das páginas.

Voltando ao Brasil, antes de me acalmar e escrever a Tese, passei ainda por uma última prova: explicar (numa apresentação oral de mais de uma hora) a teoria que havia aprendido e a parte que havia desenvolvido para três especialistas em Antônio José da Silva. Isso porque, quando minha orientadora leu meu relatório em português, recebi por email as seguintes palavras:

Passei o dia lendo e refletindo acerca de seu texto. Eu aguardava ansiosamente pela leitura do texto tendo em vista tudo que conversamos ao longo destes meses. Mas devo confessar, a leitura não foi fácil. O texto não flui. Fiquei pensando por quê. Aventei algumas hipóteses: será que você compreende a teoria em espanhol, mas quando passa para o Português, você se embanana todo? Será que os quatro meses de espanhol tornaram difícil expressar-se em vernáculo? [...] Será que a teoria trabalhada não

2 Como pertencente ao acervo da Sala Cervantes, o livro precisava de uma autorização especial para ser fotocopiado. Como o descobri de última hora, não houve tempo de conseguir a autorização. 
convence a orientadora? Será um pouco de tudo ou de algumas das hipóteses? Não sei. Reflita acerca da questão.

Desta vez, com certeza, foi Talía. A musa da máscara cômica fez valer a teoria da carnavalização e tudo o que ela pôde em uma análise acurada dos elementos cômicos de um texto. Convencidos, fui autorizado a seguir.

A partir daí, em nada a minha viagem difere da dos estudantes que, depois de muitas aventuras reais ou imaginárias, são obrigados a, num primeiro dia de aula, escrever uma redação com o tema: "como foram as minhas férias". E 491 páginas fluíram não tão fluidamente da minha humilde pena. $O$ resultado, seguramente influenciado por Fortuna, foi positivo e, no dia 05 de abril de 2017 (dia do Festival da Boa Sorte na Roma Antiga), tornei-me doutor.

A emoção foi grande, a piada foi feita e, agora, outras aventuras me esperam. Feito professor doutor, aventuro-me desta vez em águas não tão profundas, mas igualmente turbulentas. Sou professor do Ensino Fundamental II e do Ensino Médio. Que Quíron me ajude!

Submissão: 2017-05-21

Aceite: $2017-05-21$ 